\title{
Who absorbs the shock? An analysis of the fiscal impact of the COVID-19 crisis on different levels of government
}

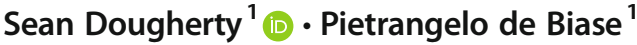

Accepted: 17 August 2021 / Published online: 23 October 2021

(C) The Author(s), under exclusive licence to Springer-Verlag GmbH Germany, part of Springer Nature 2021

\begin{abstract}
This paper discusses the fiscal impact of the COVID-19 crisis across levels of government. It contrasts the composition of revenues and expenditures of different levels of government and their main institutional differences. For revenues, an error correction model is used to estimate the short-term elasticities of different levels of government, showing that subnational governments' (SNGs) revenues are less sensitive to economic downturns than central governments', mostly because SNGs tend to rely more on recurrent taxes on immovable property. For expenditures, central governments are often responsible for the bulk of expenditure on social protection, while SNGs have a higher investment-to-revenue ratio. The combination of these differences of expenditure assignment with the substantial budget and borrowing constraints that SNGs face creates a tendency towards pro-cyclicality at the subnational level and counter-cyclicality at the central level. Furthermore, in the context of the COVID-19 crisis, in order for SNGs to have the fiscal capacity for necessary measures to tackle the outbreak, central governments supported SNGs mostly through intergovernmental grants. As a consequence, central governments have absorbed most of the shock.
\end{abstract}

Keywords Tax buoyancy · Fiscal federalism · COVID-19 crisis $\cdot$ Error correction models

\section{Introduction}

In 2020, the world faced the worst economic crisis since the Great Depression, triggered by an unparalleled pandemic of a highly contagious virus in a globalised

Sean Dougherty

sean.dougherty@oecd.org

1 Organisation for Economic Co-operation and Development (OECD), Network on Fiscal Relations across Levels of Government, Paris, France 
world. During the crisis, the budgets of all levels of government came under stress. Stress arose as a result of a "scissors effect" of contractions in revenues and increases in expenditure needs. Since different levels of government have different funding streams, expenditure assignments and degrees of fiscal autonomy, ${ }^{1}$

As of 2019, subnational governments (SNGs) in OECD countries were responsible for spending $31 \%$ of general government expenditure and collecting $15 \%$ of general government's revenues, on average, according to the OECD Fiscal Decentralisation Database. The role of SNGs is essential in making public investment, as they are responsible for, on average, half of all general government investment and also many government functions important to tackle the pandemic, such as health (31\% of general government), public order and safety $(21 \%)$ and social protection $(16 \%)$.

With responsibilities divided across levels of government, intergovernmental coordination can be problematic, which makes the overall policy setting of a country the result of a multitude of separate policies implemented by different levels of government and jurisdictions. ${ }^{2}$ Unfortunately, such a complex multi-layered structure does not make for a simple narrative and tends to be underexplored by academics and the press, with a tendency to overemphasise the role of central or national governments (Rozell and Wilcox 2019).

This article aims at filling this gap by analysing the fiscal impact of the COVID-19 crisis across levels of government as well as the fiscal measures implemented through the channel of intergovernmental relations to tackle the COVID-19 pandemic. We conclude that central governments are absorbing most of the fiscal shock, as they have been supporting SNGs through intergovernmental grants, while their revenues and expenditures tend to react more counter-cyclically than SNGs'. Preliminary data from 2020 for a sample of countries support this conclusion (see Supplementary Material A7). Nevertheless, it is still early to conclude that SNGs were not heavily impacted fiscally by the crisis, as some grants are lagged and thus SNGs may be affected with a delay in the future.

More concretely, to support SNGs' fiscal capacity to tackle the COVID-19 pandemic, central governments and central banks have stepped in, typically through additional grants, with no conditions attached, and through the lifting of fiscal rules, while a small portion of countries have provided support through loans and guarantees. ${ }^{3}$ As a result, this fiscal support has imposed costs to central governments, which

\footnotetext{
${ }^{1}$ This distribution of responsibilities across levels of government tends to benefit policymaking as (1) lower levels of government have better access to local information and preferences, (2) upper levels of government might suffer political pressure that may hinder a desired degree of policy differentiation, and (3) availability of different baskets of public goods in combination with internal mobility might increase well-being as people can move to wherever their needs are better fulfilled (Hindriks and Myles 2013) their vulnerability to shocks varies.

2 Ter-Minassian (2020) shows that designing effective intergovernmental fiscal cooperation arrangements is far from trivial and may depend on several factors such as having a strong national government that exercise effective policy leadership, ethnic tensions, natural resources endowments, levels of development, economic structure and even history of perceived unfairness by the national government in resource distribution across SNGs. Dougherty et al. (2020) and de Biase and Dougherty (2021) explore intergovernmental coordination arrangements to tackle the COVID-19 crisis and reveal issues that countries have in coordinating their responses.

${ }^{3}$ In the sample of countries analysed, the most common response from central governments has been the provision of extraordinary grants (13 out of 23 countries). Nine countries have temporarily lifted fiscal and in six countries the central government has provided additional loans and guarantees to SNGs.
} 
affect central governments' debt levels, in place of SNGs' indebtedness. With regard to revenues, the short-run total tax buoyancy for central governments is, in most countries, higher than for SNGs. As a result, SNGs' own tax revenues are more stable in times of crises. This can be explained by the fact that there is a tendency for SNGs to rely more on recurrent taxes on immovable property, which is a more stable source of revenue, while SNGs' personal income tax revenues tend to be less buoyant than those of central governments'.

Concerning expenditures, as central governments are responsible for economic stabilisation, they tend to have more counter-cyclical expenditures and their expenditures tend to increase the most in times of macroeconomic crises. More specifically, as a percentage of their revenues, SNGs tend to spend more on investment, consumption and personnel, while central governments tend to spend more on social benefits and current transfers. To tackle the COVID-19 crisis, fiscal stimulus has been enormous, as governments already deployed US\$16 trillion from the beginning of the pandemic through mid-March 2021 (IMF 2021). Much of this stimulus was deployed by central governments, damaging their finances.

These conclusions are drawn from a multi-country case study of key OECD and partner economies and are, thus, relatively broad, which is a distinctive feature of this article. Other studies on the reaction of SNGs' fiscal aggregates to economic activity tend to cover only a specific country. Clemens and Veuger (2020) estimated expected revenue shortfalls as a result of the COVID-19 crisis for US states and local governments using employment data. Anderson and Shimul (2018) and Bruce et al. (2006) estimated the long-run and short-run elasticity of US state and local tax revenues by tax type using error correction models. Shoag et al. (2017) examined the influence of local autonomy on the responses to negative revenue shocks in the United States. Kodrzycki (2014) explored why elasticity levels differ across US states and over time. Jonas (2012) analysed how the Global Financial Crisis affected US SNGs finances.

More comprehensive studies tend to analyse the reaction of fiscal aggregates only from a central or national government perspective and they usually differ with regard to the methods employed. Lagravinese et al. (2020), Deli et al. (2018), Dudine and Jalles (2017), Köster and Priesmeier (2017), Mourre and Princen (2015), Belinga et al. (2014), Koester and Priesmeier (2012) and Wolswijk (2009) estimate tax buoyancy or elasticity for general governments of various countries using variations of error correction models to capture dynamic effects. Price et al. (2015) estimated the elasticities of both government revenue and expenditure items with respect to the output gap for European Union countries. Thus, the comparison of short-term buoyancy by level of government across countries provided in this piece is novel and potentially the first of its kind.

Our discussion and analysis proceed as follows. In section 2 we delve into the methods employed, contrasting these with similar studies. In section 3 we explore revenue and expenditure items by level of government as well as structural differences that might change their expected reaction to crises. In section 4 we show the model's results. In section 5 we examine the fiscal measures employed through the channel of

\footnotetext{
${ }^{0}$ In the sample of countries analysed, the most common response from central governments has been the provision of extraordinary grants (13 out of 23 countries). Nine countries have temporarily lifted fiscal and in six countries the central government has provided additional loans and guarantees to SNGs.
} 
intergovernmental relations to tackle the COVID-19 crisis, which we obtained from a survey of the OECD Network on Fiscal Relations across Levels of Government. We close this research discussing the implications of the main results of the aforementioned sections.

\section{Methods}

This paper builds on a survey of countries' responses to the pandemic, collected in June 2020 by the OECD Network on Fiscal Relations across Levels of Government. In addition to the descriptive and theoretical analysis of the properties of the measures implemented by countries to support SNGs fiscal capacity, this research draws on data from the OECD Fiscal Decentralisation Database and OECD System of National Accounts to analyse the reaction of revenues of different levels of government to economic activity through the use of tax buoyancy estimates. The composition of government expenditure of each level of government is explored but not modelled, as most expenditure items bear no direct relation to the cycle and are a result of exogenous decisions made during the development of a government's budget. ${ }^{4}$

\subsection{Definition of elasticity}

The response of tax revenues to changes in economic activity can be measured through the use of tax elasticity and tax buoyancy. These concepts are useful for explaining the overall structure of tax systems and, thus, can be used to aid the design of tax policy (Jenkins et al. 2000).

Traditionally, the elasticity of tax revenues is estimated with respect to (1) specific tax bases, ${ }^{5}(2)$ the output gap, ${ }^{6}$ or (3) GDP. ${ }^{7}$ This study applies the third option for three reasons. First, GDP enhances comparability across countries and levels of government as it is a standardised and observable variable, while the output gap that must be estimated based on assumptions on potential GDP, and effective tax bases are a function of the tax policy, which differs across countries and levels of government. Second, as the first of its kind (i.e., a cross-country analysis of the reaction of revenues of different levels of government), it is reasonable to employ a more widely used method to enhance its comparability to other pieces of research. Third and lastly, according to Köster and Priesmeier (2017), previous studies suggest that estimations based on output gaps and GDP tend to have similar results and, in this case, a simpler method is preferred.

\footnotetext{
${ }^{4}$ For instance, for Price et al. (2015) the only element of spending that can be defined as cyclically sensitive is related to unemployment benefits, and it is sensitive to the unemployment rate rather than to output. In addition, these authors acknowledge that there is a high and difficult-to-explain dispersion across countries in the empirical estimates for income-related benefits.

${ }^{5}$ Recent examples: Princen et al. (2013).

${ }^{6}$ Recent examples: Price et al. (2015).

${ }^{7}$ Recent examples: Lagravinese et al. (2020), Anderson and Shimul (2018), Deli et al. (2018), Dudine and Jalles (2017), Köster and Priesmeier (2017) and Belinga et al. (2014).
} 


\subsection{Justifying the use of tax buoyancy}

The reaction of tax revenues to economic activity is typically measured through the use of tax elasticity or buoyancy. The former controls for discretionary and automatic tax changes by removing from the time series the ex ante estimated effects of tax policy changes, whereas the latter does not have such controls and, thus, is just the overall change of tax revenues that results from a one percentage change in the level of GDP. Since tax elasticity captures the effect of the cycle in isolation, some authors consider it to be the best indicator to measure the reaction of tax revenue to changes in the macroeconomic conditions (Jenkins et al. 2000). There are also compelling arguments in favour of using tax buoyancy, however. Lagravinese et al. (2020) suggests that: (1) discretionary tax changes are part of fiscal policy and, thus, should be captured by the indicator, (2) there is no guarantee that ex ante estimation of the impact of tax changes can be perfectly disentangled from ex post tax revenues, leading to biases that tend to increase in cross-country comparisons due to differences in accounting rules or how exogenous tax policy changes are defined.

This research focuses on analysing the fiscal reaction of levels of government to the COVID-19 crisis and, for that purpose, it analyses the short-term reaction of their tax revenues to economic activity. In this case, the proper use of tax elasticity would require an estimation of the impact of tax changes that have occurred in the previous decades segregated by level of government and country. As SNGs have multiple jurisdictions with their own tax policies, it would be necessary to make such an estimate for thousands of jurisdictions. This demanding endeavour poses substantial risk of completeness and of comparability as there is no cross-country harmonized dataset of such measures. For these reasons and in line with other authors (Lagravinese et al. 2020; Deli et al. 2018; Dudine and Jalles 2017; Belinga et al. 2014), this piece uses tax buoyancy instead of elasticities.

Lastly, the use of short-run tax buoyancy captures discretionary tax changes that are made with the purpose of smoothing the reaction of tax revenues to the cycle. In other words, tax buoyancy measures both the soundness of the tax bases and the effectiveness of a tax. As these changes are common for some types of taxes and in some countries (e.g., in recurrent property taxation in the United States ${ }^{8}$ ), controlling for them would go against the purpose of the analysis. More specifically, since this study focuses on the impact of the COVID-19 crisis on different levels of government, it would be unreasonable to ignore the fact that SNGs from some countries have the autonomy to change their tax policies and often use this autonomy to change their tax policy with the purpose of protecting their budgets from crises or downswings. This is a valid tool that can be and is employed to dampen reductions in tax revenues and, therefore, should not be ignored.

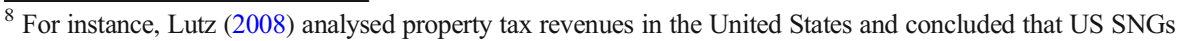
tend to make discretionary changes to their property tax rates to make tax revenues more stable regardless of what happens to GDP and house prices. In other words, SNGs compensate for revenue losses in times of crises by increasing property tax rates and smooth tax hikes due to increase in property prices adjusting statutory tax rates downwards.
} 


\subsection{Methodology for estimating the reaction of tax revenues - error correction model}

Multiple methods are employed to estimate tax elasticities and buoyancies. The simplest and most widely used method is to regress the natural logarithm of tax revenue on the natural logarithm of GDP, as employed by, for instance, Jenkins et al. (2000) and Haughton (1998). Recent studies, however, have been employing more complex methods in order to capture the dynamic relationship between tax revenues and the GDP through error correction models (ECM). Variations of ECM are used to estimate tax buoyancy or elasticity by, for instance, Lagravinese et al. (2020), Deli et al. (2018), Köster and Priesmeier (2017), Dudine and Jalles (2017), Mourre and Princen (2015), Belinga et al. (2014), Koester and Priesmeier (2012), Wolswijk (2009) and Bruce et al. (2006).

These ECMs assume that there is a long-run and short-run relationship between tax revenues and the GDP and that the short-term deviations from the long-run relationship are continuously adjusting towards the long-run relationship at a certain speed. As a result, ECMs estimate three coefficients of interest: the short-run, long-run and speed of adjustment coefficients. Naturally, some of these coefficients are more relevant than others, depending on the goal of the research at hand. For instance, an analysis of the impact of the economic cycle on tax revenues should focus more on the short-run coefficients, while an analysis of fiscal sustainability should focus more on the long-run ones. Needless to say, this piece will focus on the short-term coefficients, as the goal of this analysis is to assess the potential impact of the COVID-19 crisis on the finances of different levels of government.

To avoid a spurious time series relationship between GDP and tax revenues, this piece estimates dynamic tax buoyancy using the two-step approach of Engle and Granger (Enders 2014). This method was also employed to estimate tax buoyancies or elasticities by a myriad of authors such as Wolswijk (2009), Koester and Priesmeier (2012), Mourre and Princen (2015) and Köster and Priesmeier (2017). Unit root tests can be found in the Supplementary Material A1.

First, the long-run relationship, represented by the $\beta_{c, l, t}$ coefficient, is estimated using ordinary least squares (OLS). ${ }^{9}$ The following equation was estimated:

$$
\ln \left(T R_{c, l, i, t}\right)=a_{c, l, t}+\beta_{c, l, t} \ln \left(G D P_{c, l, i}\right)+v_{c, l, t} D_{u m m y}{ }_{c, i}+\epsilon_{c, l, i, t}
$$

Where $T R, a, \epsilon, c, l, i$ and $t$ refer to tax revenues, intercept, an error term, country, level of government, time (in years) and tax type, respectively. To control the long-run buoyancy estimation for the occurrence of economic crises, a dummy is introduced (i.e., dummy is equal to a unit when the real GDP growth rate of a country is negative and 0 otherwise). ${ }^{10}$

\footnotetext{
${ }^{9}$ The use of OLS in this setup is not a problem as it can be proven that it yields a super-consistent estimator of the cointegrating parameters (Enders 2014).

${ }^{10}$ Resorting to dummies to control for specific phases of the cycle is commonplace and is employed by, for instance, Lagravinese et al. (2020), Deli et al. (2018), Mourre and Princen (2015) and Belinga et al. (2014).
} 
Second, the ECM is estimated using the following equation, which has the lagged errors from the previous equation as an independent variable together with the first differences of GDP:

$$
\Delta \ln \left(T R_{c, l, i, t}\right)=\gamma_{c, l, t}+\alpha_{c, l, t} \epsilon_{c, l, i-1, t}+\rho_{c, l, t} \Delta \ln \left(G D P_{c, l, i}\right)+\partial_{c, l, t} D_{u m m y} y_{c, i}+\varepsilon_{c, l, l}(2)
$$

Where $\gamma, \alpha, \rho, \partial$ and $\varepsilon$ represents an intercept, the speed of adjustment, the short-run buoyancy, the dummy coefficient and an error term, respectively.

The mean group estimator was employed and, therefore, the model allows for heterogeneity of all estimated parameters, including variances. This setup can be justified by the fact that coefficients tend to vary across countries, at least at the general government level, as other cross-country studies have shown. ${ }^{11}$ At lower levels of government, this heterogeneity is also expected and it might even be larger, as SNGs tend to have widely different revenue portfolios that vary with the degree of decentralisation in the country (Dougherty et al. 2020). Pooling data and using fixed effects approaches in this situation might produce inconsistent and misleading results.

The result of this baseline model is compared to the results of two other models as a robustness check:

- The first of these alternative models is an one-stage approach ECM, which estimates all coefficients (short-term buoyancy, long-term buoyancy and speed of adjustment) through a single auto regressive distributed lag (ARDL) equation this ECM variation treats all variables symmetrically in contrast to the two-stages approach ECM (Enders 2014). ${ }^{12}$ No dummy variables were used.

- The second of these models is the same two-stage ECM, but using a robust regression instead of OLS. ${ }^{13}$ Robust estimators can be almost as efficient as least squares when the error distribution is normal, and much more efficient when the errors are heavy tailed (Fox 2015). As we are assessing tax buoyancy across levels of government, one-off events related to (de)centralisation of tax revenues or to substantial changes to tax policy might create outliers that can bias an OLS, as OLS are sensitive to outliers. This estimator will, therefore, control for such events.

\subsection{Data}

All the data used come from the OECD Revenue Statistics. The period analysed spans from 1990 until 2019, but it might differ by country depending on data availability (Supplementary Material A2 shows the data availability by each of the 37 countries). Although in principle an unbalanced panel was used, the differences in data availability are minimal and capped at 5 years. This period includes the entirety of the Global Financial Crisis and, therefore, the impact of the crisis on tax revenues.

\footnotetext{
${ }^{11}$ See, for instance, Lagravinese et al. (2020), Dudine and Jalles (2017), Deli et al. (2018) and Belinga et al. (2014).

${ }^{12}$ Variations of this model were used by a myriad of authors for estimating tax elasticity or buoyancy, such as Lagravinese et al. (2020), Deli et al. (2018), Dudine and Jalles (2017) and Belinga et al. (2014).

${ }^{13}$ More precisely, a MM-type regression estimator is used, as described in Yohai (1987) and Koller and Stahel (2011), which are especially good for small samples, for estimating the 1st and 2nd stages of the ECM.
} 
Each cross-sectional unit refers to a combination of one of the 37 countries and the respective level of government. As countries might have a varied number of levels of government, this study grouped all lower level of governments into the "subnational level" to enhance comparability. Similarly, revenues from the social security system were grouped along with those of the central governments. Therefore, in this setup each country has two levels of government: the central level (i.e., consisting of central government and social security) and the subnational level (i.e., consisting of local and, if applicable, state/regional levels) while the general government level is the aggregation of all of them. Estimations used local currency.

The tax types analysed are those at the highest level of aggregation from the OECD Revenue Statistics with the exception of income taxes that are segregated by taxes on business and individuals. That is, the following six tax types are analysed: personal income taxes (PIT), corporate income taxes (CIT), social security contributions (SSC), payroll taxes, property taxes and goods and services taxes (GST). Total taxes are also analysed and refer to the aggregation of all types of taxes, including taxes other than those just described (see Supplementary Material A3 for more details). Using higher resolution data in the estimation of the coefficients creates bias as the dataset is not as complete for sub-items of tax revenues for some levels of government. In addition, the lower the resolution of the data, the higher the impact of tax type specific exogenous factors, potentially increasing biases. Higher resolution data is, though, used in an exploratory manner to make conjectures on the results of the coefficients estimated.

It is worth highlighting that the data from the OECD Revenue Statistics are harmonised and treated. In other words, data from this dataset enhances cross-country comparisons as they represent the same type of taxes, avoiding the situation in which different countries classify their taxes heterogeneously. Therefore, biases related to tax categorisation are minimised.

\subsection{Survey}

The OECD Network on Fiscal Relations across Levels of Government surveyed its members and partners on the responses that governments took through the channel of intergovernmental fiscal relations to tackle the Coronavirus (COVID-19) crisis. Twenty-three OECD and partner countries answered the survey. This sample consists of a variety of countries from five continents that differ substantially in size, demography and socio-economic factors (see Supplementary Material A4).

From the 19 questions asked, this paper explores the answers to two of them, which are directly related to the distribution of the impact of the COVID-19 crisis across levels of government. Both questions relate to the measures that central governments took or have been taking to ensure that SNGs have sufficient liquidity to cope with the crisis (see the full questions in Supplementary Material A4).

\section{Revenue and expenditure structure by level of government}

Fiscal federalism refers to the delineation of activities related to revenue collection and expenditure responsibilities across levels of governments. In principle, lower levels of government can gather more precise information on local preferences than those at 
upper levels and, therefore, can define and implement policies that better suit people's needs. In the case that consumers have heterogeneous preferences, aggregate welfare will be superior when each jurisdiction is allowed to select its own policies as opposed to when uniform policies are implemented across all jurisdictions (Oates 1972).

Nevertheless, decentralisation also has disadvantages. Notably, interregional tax competition, failure to exploit economies of scale and inappropriate risk sharing through the federal fiscal system (Hindriks and Myles 2013). In addition, regional governments might have problems dealing with regional spill-overs (i.e., where the impact of policies implemented by one jurisdiction affects other jurisdictions).

Due to these trade-offs, it is not trivial to determine the welfare-maximizing degree of decentralisation and, thus, countries differ on the delineation of expenditure and tax collection responsibilities that are decentralised. ${ }^{14}$ As the level of economic activity affects different revenue streams and expenditure needs heterogeneously, levels of government are expected to have a different exposure to crises.

\subsection{Revenue structure of different levels of government}

In theory, it is expected that SNGs will have a less diversified tax mix than those of the central government, as not all taxes are well-suited to be collected at the subnational level. First, due to economies of scale in tax collection, it is often better for SNGs to collect few taxes with large revenue capacity than multiple taxes with small revenue capacity (Mikesell 2012). Second, mobile tax bases are prone to tax competition, since taxpayers can move their residence (or move the tax base - e.g., capital) to jurisdictions with more favourable tax policy, leading to a loss of tax base by one jurisdiction and a gain to the other, but reducing the overall capacity of the tax system to collect revenues (Blöchliger and Pinero 2011). Therefore, large taxes and immobile tax bases are, at least in theory, appropriate to be ascribed to lower levels of government.

An analysis of the composition of tax revenues of different levels of government confirms the theoretical expectation. Figure 1, which shows the composition of tax revenues by tax type across levels of government in OECD and partner countries, reveals that SNGs tend to rely substantially more on property taxes than central governments. This can be explained by the fact that one of the most important taxes is the recurrent levy on immovable property. Other relevant differences between SNGs and central governments are that the former have: (1) a wider variation in their reliance on income taxes (2) less reliance on goods and services taxes and (3) non-significant reliance on social security contributions.

Looking closer to the composition of property tax revenues at different levels of government, it seems that it is indeed the case that property taxes are more representative at lower levels of government due to the high share of recurrent taxes on immovable property at the subnational level (Fig. 2). Aside from Switzerland, SNGs from all other OECD countries have a high share of recurrent taxes on immovable property as a percentage of their total property tax revenues.

For central governments, on the other hand, taxes on financial and capital transactions are the most representative type of property tax. Nevertheless, it is worth noting

\footnotetext{
$\overline{{ }^{14}}$ See, for instance, Dougherty and Phillips (2019) and Dougherty et al. (2019) for an in-depth analysis of the cross-country differences in subnational spending power and tax autonomy.
} 
Level of government

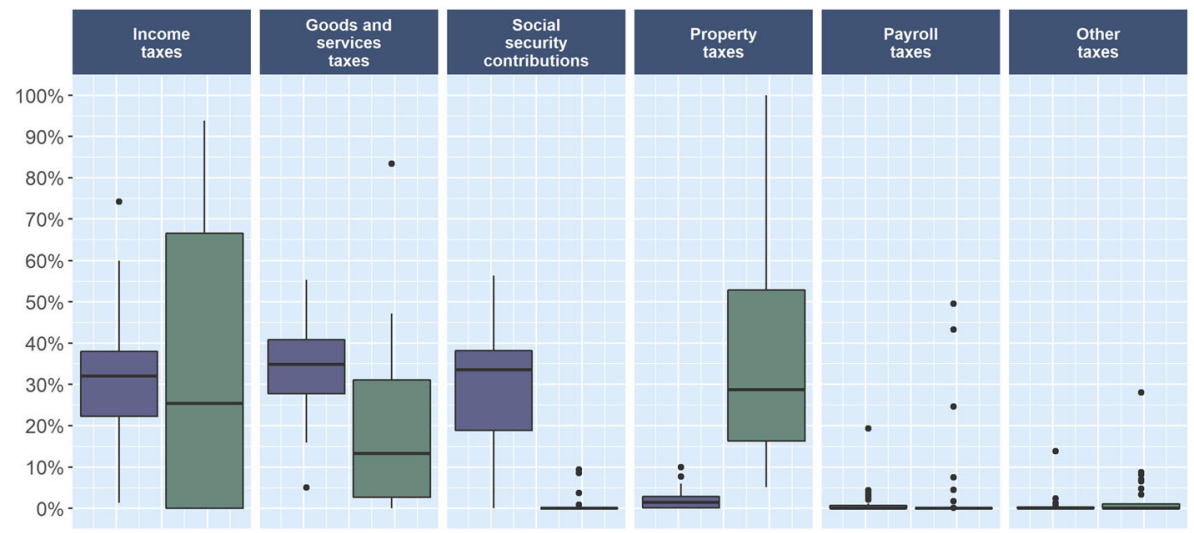

Fig. 1 Composition of tax revenues across levels of government. OECD countries. Note: Values of 2019 or closest year. Source: Authors' elaboration based on OECD Revenue Statistics

that even though taxes on financial and capital transactions tend to be important in comparison to other property taxes (Fig. 2), property taxes are often negligible as a source of income for central governments (Fig. 1).

Another major source of SNGs' revenues is intergovernmental grants. In no country are SNGs' own tax revenues sufficient to cover all their expenditures and, therefore, this gap is filled with grants from the central government. ${ }^{15}$ This aspect of fiscal federalism is known as the vertical fiscal gap. On average, SNGs in OECD countries are responsible for raising $54 \%$ of their revenues, while $46 \%$ of their revenues come from grants (Fig. 3, circles).

Not only does the dependency on grants vary widely across countries but also the rules that apply to them. ${ }^{16}$ Intergovernmental grants are a broad instrument that are employed to achieve a myriad of goals. Previous studies suggest that grants are more volatile and also more pro-cyclical than SNGs' tax revenues and, in addition, they have a tendency to react with a lag of 1-2 years to the economic cycle as a result of their formulas (Blöchliger et al. 2010b).

\subsection{Expenditure structure of different levels of government}

Regarding expenditures, two different and complementary classifications are explored: (1) a classification of transactions from the OECD System of National Accounts and (2) a classification of the Functions of Government (COFOG). The first aims at characterising the relationship of the expenditure with the economy and is particularly insightful in assessing a government's margin of manoeuvre for changing the allocation

\footnotetext{
${ }^{15}$ Data from the OECD Fiscal Decentralisation Database reveal that, in all OECD countries, SNGs' own revenues are insufficient to meet their expenditures.

${ }^{16}$ See, for instance, Bergvall et al. (2006).

${ }^{0}$ For instance, personnel expenditure tends to be more rigid (i.e., difficult to adjust in the short-term) than investments. Hence, a government whose personnel expenditure represents most of its expenditures might face more challenges to adjust their expenses in comparison to a government that has invested more. See Mattina and Gunnarsson (2007) for a case study on budget rigidity.

${ }^{0}$ For instance, social protection tends to be a higher priority in times of crisis (Blöchliger et al. 2010a).
} 
Level of government



Fig. 2 Composition of property tax revenues across levels of government. OECD countries. Similar plots for other types of taxes are shown in Supplementary Material A5. Note: Values of 2019 or closest year. Source: Authors' elaboration based on OECD Revenue Statistics

of public funds. ${ }^{17}$ The second distinguishes government expenditures in respect of their purpose and, thus, is useful for assessing a government's priorities, which tend to be affected by crises. ${ }^{18}$

Looking at expenditures classified in transactions (Fig. 4), it becomes clear that the distribution of the shares of SNGs' expenditure composition in transactions have a small dispersion in comparison to the distribution of their revenues. In addition, SNGs tend to spend more on personnel, intermediate consumption and investment, while central governments tend to spend more on social benefits and current transfers.

In terms of volatility, personnel spending is the least volatile, while investment is often the most volatile type of expenditure (Mattina and Gunnarsson 2007), as in times of necessity, SNGs tend to reduce investment (Blöchliger et al. 2010a). On the other hand, central governments tend to spend significantly on social benefits, which tends to be a cyclically-sensitive spending item (Price et al. 2015) and on current transfers, which can also be under pressure in crises, as central governments may boost intergovernmental grants to stabilise SNGs revenues (Blöchliger et al. 2010b).

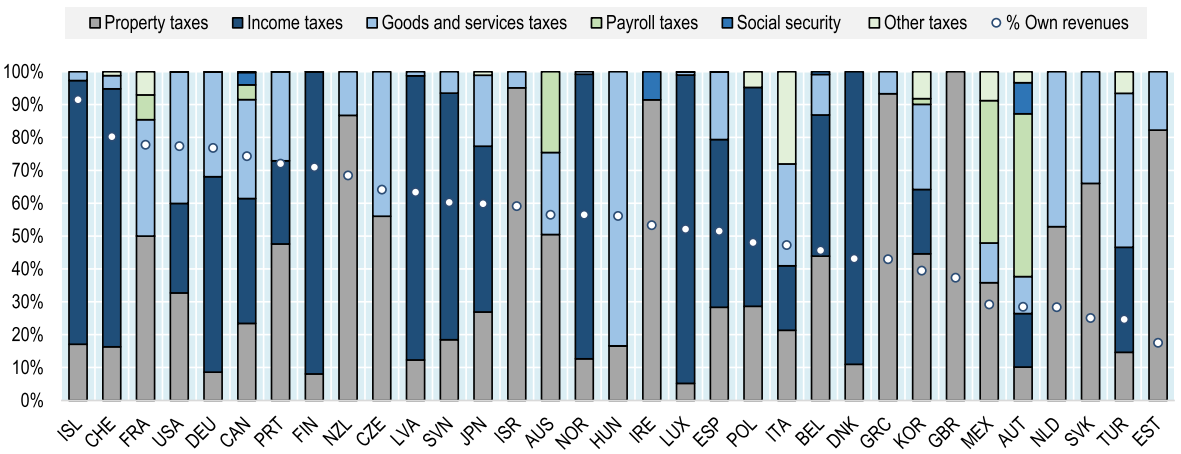

Fig. 3 Composition of (1) SNGs' own tax revenue by tax type (bars) and (2) SNGs' total revenues by own revenues or grants (bullet). OECD countries. Note: Values of 2019 or closest year. Source: Authors' elaboration based on OECD System of National Accounts and OECD Fiscal Decentralisation Database 
The composition of SNGs' budgets in terms of government functions vary substantially (Fig. 5). For instance, although on average, SNGs spend the largest share by function on education, SNGs from several countries do not even spend on this function. Similar patterns can be seen with health and social protection expenditure, which are, respectively, the 5 th and 2 nd most representative functions in terms of spending. Central governments from all countries, on the other hand, have a substantial portion of their budget consisting of expenditures related to social protection.

\subsection{Fiscal policy across levels of government}

SNGs tend to have more budget rigidity than central governments because: (1) they have limited autonomy to increase revenues as they are typically dependent on intergovernmental grants and rarely have full discretion over their tax policies (Dougherty et al. 2019), (2) they have to comply with a wide diversity of fiscal rules and (3) they face institutional borrowing constraints (Vammalle and Bambalaite 2021) or have a less developed and more illiquid bond markets in comparison to national bond markets (Roland and Smoke 2005). As a result, they cannot easily roll-out debt or compensate for revenue shortfalls by issuing debt, as central governments do. In addition, they also have to comply with a myriad of fiscal rules. Cutting discretionary spending such as investment often becomes the easiest path to adjust their budgets. ${ }^{19}$

For these reasons, SNGs are more vulnerable than central governments to liquidity crises and they tend to act more pro-cyclically as a result, potentially strengthening the effect of downswings. Figure 6 shows that to tackle the Global Financial Crisis, central governments reacted more counter-cyclically and recovered their financial position later than SNGs. This can be partially explained by the fact that as soon as 2010, SNGs started to reduce investment significantly (Fig. 7). It is worth highlighting that SNGs are responsible for more than half of all government investments in OECD countries $^{20}$ and, thus, the impact of this fiscal policy on national growth rates can be substantial.

\section{Model results}

\subsection{Analysing the distribution of individual coefficients}

Despite small differences in the estimation of the three models (Fig.8) (Fig. 9) (Fig. 10), some general conclusions can be drawn:

- PIT: The distribution of PIT short-term buoyancies for SNGs is shifted slightly down in comparison to that of central governments. In all models the median of the distribution is slightly smaller for SNGs in comparison to that of central governments.

\footnotetext{
${ }^{19}$ For instance, Kodrzycki (2014) analysed this topic in the United States and concluded that state governments tend to employ pro-cyclical fiscal policy by reducing discretionary spending so as to close their budget gaps.

${ }^{20}$ Estimation based on OECD System of National Accounts.
} 
Level of government

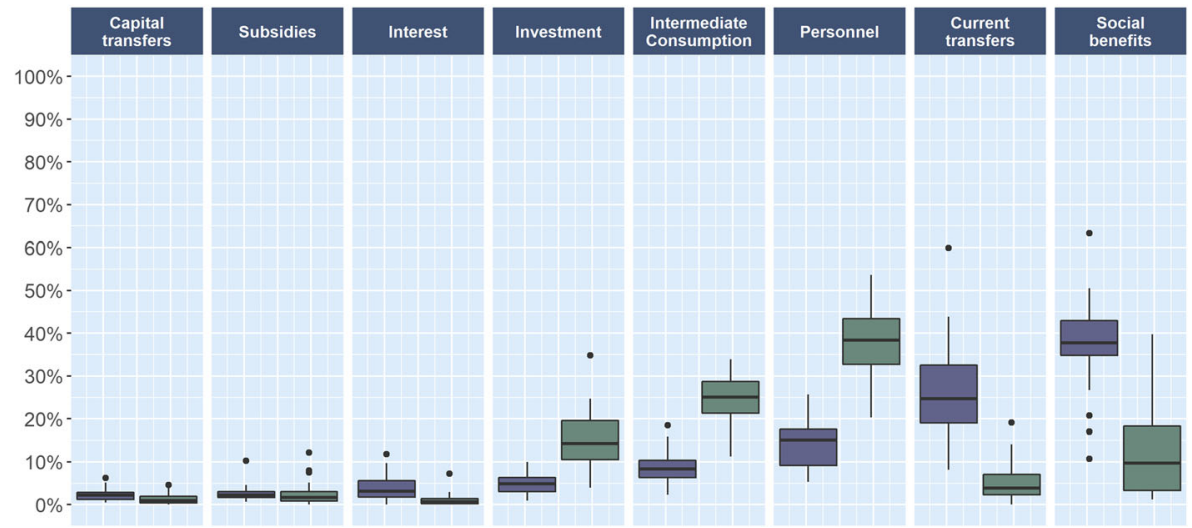

Fig. 4 Composition of expenditures by transaction across levels of government. OECD countries. Note: Values of 2019 or closest year. Source: Authors' elaboration based on OECD System of National Accounts

- CIT: The distribution of CIT short-term buoyancies for SNGs and central governments vary substantially depending on the model employed and, therefore, no robust conclusion can be drawn.

- SSC: SSC are by and large only relevant for central governments (refer to Fig. 1) and, thus, no relevant conclusion can be drawn with regard to the differences in SSC buoyancies across levels of government.

- Payroll taxes: Payroll taxes are by and large not a major source of revenues for either central governments or SNGs. Only in seven countries of our sample do SNGs have revenue from payroll taxes (see Supplementary Material A6). Both the 1st and 2nd stage non-robust ECMs suggest that payroll tax buoyancies tend to be higher for SNGs but the ECM using a robust estimator does not support this

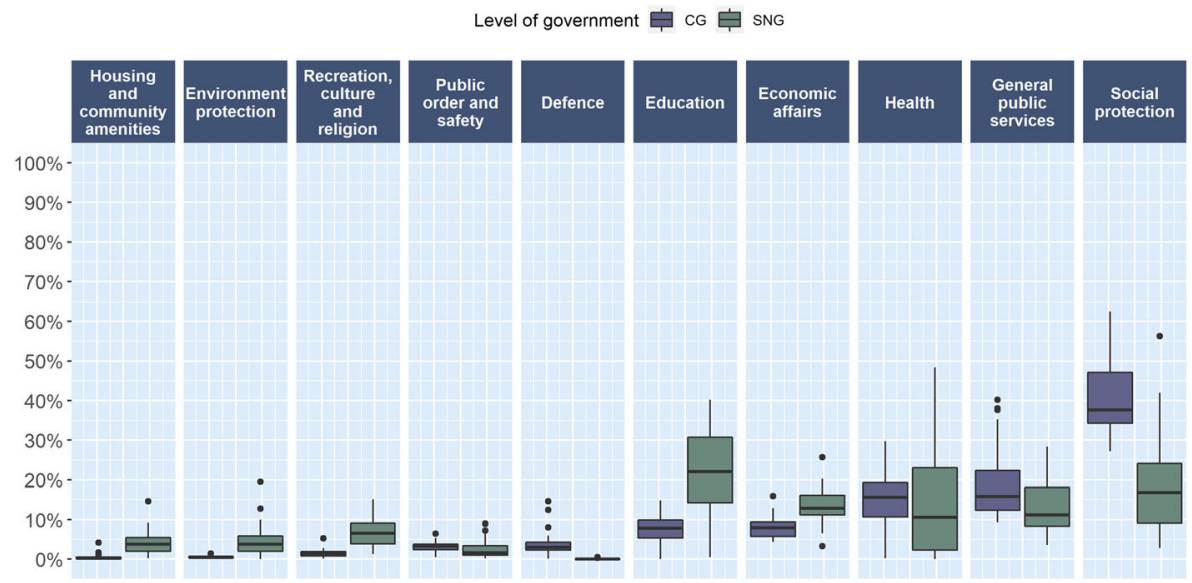

Fig. 5 Composition of expenditures by function across levels of government. OECD countries. Note: Values of 2019 or closest year. Source: Authors' elaboration based on OECD System of National Accounts 


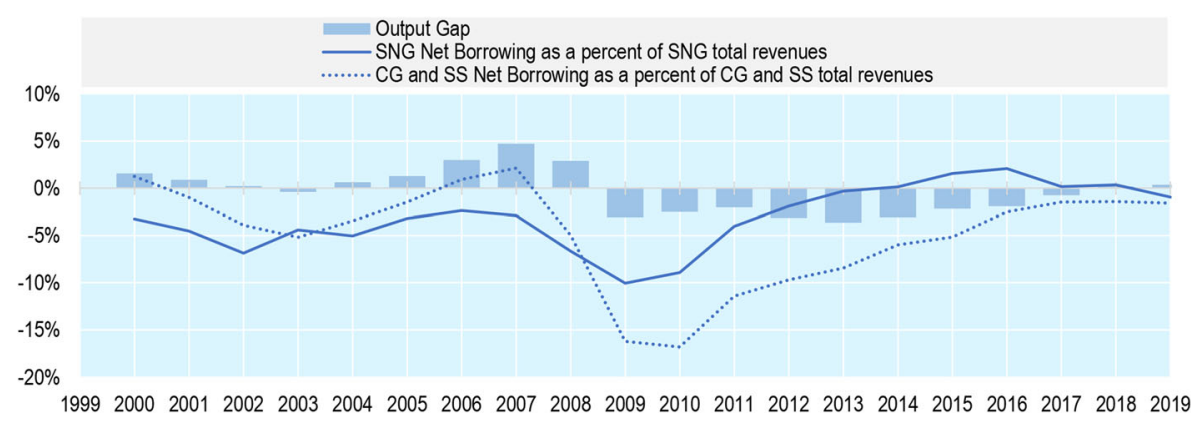

Fig. 6 Central governments' fiscal balances fluctuate more and are more affected by crises than SNGs'. OECD countries. Note: Consolidated revenues and fiscal balances. CG and SS refer to central government and social security, respectively. Source: Authors' elaboration based on OECD Fiscal Decentralisation Database

conclusion. Therefore, due to the small number of observations at the subnational level and to the substantial different estimations when using a robust estimator, it is likely that the results from the 1st and 2nd stage non-robust ECMs were influenced by outliers. No clear conclusion can be drawn.

- Property taxes: All three models suggest, to some extent, that property tax revenues tend to be less buoyant at the subnational level than at the central level. In all models the median of the distribution is slightly smaller for SNGs in comparison to that of central governments. In the case of the 1-stage ECM, the distribution of property tax short-term buoyancy is substantially shifted down while in the case of the 2-stage non-robust ECM, the distribution is slightly shifted down. When using a robust estimator for the ECM, the distribution of property tax short-term buoyancy for SNGs has a smaller dispersion and is slightly shifted down as well.

- GST: All three models suggest that the dispersion of GST tax buoyancy is higher at the subnational level than at the central level. Nevertheless, estimations are not clear whether SNGs or central governments tend to have a higher GST tax buoyancy as the medians and the box plots positions vary across models.



Fig. 7 Pro-cyclical fiscal policy at subnational level: SNG investment usually fluctuate more than central governments in times of crisis. OECD countries. Note: Gross capital formation is used as a proxy for investment (GP5P) and is presented as a percent of Total Revenue (GTR) of the respective level of government. CG and SS refer to central government and social security, respectively. Source: Authors' elaboration based on OECD System of National Accounts 
- Total tax revenues: All three models suggest that SNG short-term buoyancies tend to be slightly lower than that for central governments given that the median is lower, and the distribution is slightly shifted down for SNGs in comparison to central governments. Nevertheless, the dispersion of the total tax buoyancy is also higher for SNGs in comparison to central governments in all three estimations.

\subsection{Mean group estimator}

An analysis of the results of the mean group estimator (Fig. 11) offers interesting insights. First, property taxes tend to be the least buoyant tax at the subnational level but the 2 nd most buoyant at the central level. Likely this is because property taxes at the subnational level tend to refer to recurrent taxes on immovable property (refer to Fig. 2) and their tax bases are principally properties' capital values (Almy 2014). Therefore, it is expected that these taxes are going to follow the asset cycle, which can differ strongly from the typical economic cycle (Princen et al. 2013). If that is the case, it is expected that SNGs that rely more on recurrent taxes on immovable property would have a smaller short-term buoyancy. Figure 12, below, shows that, indeed, there is a tendency for SNGs that rely more on property taxation to have more stable revenues (i.e, less short-term buoyancy).

Second, the relative order of the short-run buoyancy of tax types for the central government $^{21}$ is rather similar to the results of other studies, the exception being the relative order of SSC and GST, where SSC tend to be more buoyant than GST. ${ }^{22}$ It is important to note that these other studies analyse the tax elasticity or buoyancy at the aggregate level and, thus, their analysis includes central governments and SNGs in aggregate. As SNG GST buoyancy is higher than central government GST buoyancy, according to the results of our mean group estimator, the divergence between this piece and others would likely vanish if the estimation were replicated at the general government level.

\subsection{Autonomy}

There is evidence that the degree of autonomy of SNGs is correlated with the speed with which they recover their finances from negative shocks (Shoag et al. 2017) and this can be at least partially explained by the fact that autonomous SNGs tend to increase tax rates in times of crises to stabilise their revenues (Lutz 2008). ${ }^{23}$ As tax buoyancy captures exogenous tax policy changes, it is worth testing this conclusion.

\footnotetext{
${ }^{21}$ It is worth noting that most other studies analyse tax buoyancy or elasticity at the general government level. As the bulk of tax revenues are concentrated at the central level, we chose to compare the results of these studies to our central government estimations.

${ }^{22}$ Lagravinese et al. (2020) estimated the short-term buoyancy for CIT, PIT and GST and concluded that CIT are the most buoyant type of tax, followed by PIT and GST, in this order. Dudine and Jalles (2017) concluded that CIT is the most buoyant tax followed by PIT, GST and SSC. Belinga et al. (2014) arrived at the same order as Dudine and Jalles (2017), while Mourre and Princen (2015) found that GST is the most buoyant followed by CIT, PIT and SSC.

${ }^{23}$ Study covers only the United States.
} 


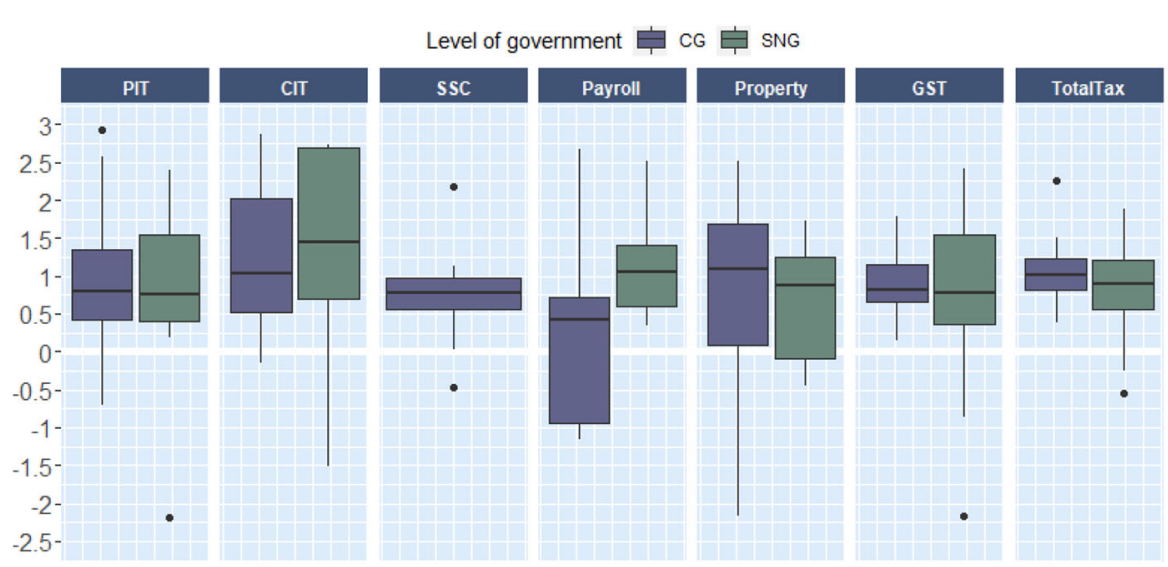

Fig. 8 Boxplot of the short-run buoyancy coefficient (y axis) of the baseline model (2-stage ECM using OLS) by level of government and tax. For visualisation purposes, values are capped between -2.5 and +3 . See Supplementary Material A6 for a detailed description of coefficients. Source: Authors' elaboration based on the OECD System of National Accounts

That is, is the tax autonomy of SNGs correlated with tax revenue stability (i.e., having a lower short-term buoyancy)?

Using the tax autonomy indicator from the OECD Fiscal Decentralisation Database, it is interesting to note that these variables are indeed correlated. Figure 13 shows that SNGs that have a low tax autonomy tend to have higher total tax short-term buoyancies. Although the same conclusion can be drawn considering the coefficients from the three different models, a more robust analysis is necessary to check whether there is causality.

\section{Fiscal measures through the channel of intergovernmental relations to tackle COVID-19}

As mentioned in the second section, SNGs have limited autonomy to increase revenues, have to comply with a wide diversity of fiscal rules and face borrowing constraints, which makes them more vulnerable than central governments to liquidity crises. Aware of these limitations, central governments usually support SNGs in these crises, as the former can issue sovereign debt with ease. As a result, SNGs are said to face a soft budget constraint (Eyraud et al. 2020).

This support from central governments faces its own limitations, though. It is true that central governments are substantially larger than any individual jurisdiction ${ }^{24}$ and, thus, an extraordinary support to an individual jurisdiction will very likely not harm the fiscal sustainability of the central government. Nevertheless, a systemic crisis involving multiple government units might increase central debt levels in an unsustainable

\footnotetext{
${ }^{24}$ Data from 2019 from the OECD Fiscal Decentralisation Database shows that only in 4 out of 32 OECD countries (Canada, Denmark, Switzerland and Sweden) all SNGs put together are responsible for more expenditures than the central government. Thus, using the share of expenditure by level of government as a proxy for their "fiscal relevance", it is clear that central governments are very likely to be substantially larger than any individual jurisdiction.
} 
manner (Rodden 2002). In addition, expected bailouts by the central government may create incentives for SNGs to act in an irresponsible manner, as central government reputation is key for reducing subnational over-borrowing (Dovis and Kirpalani 2020). For these reasons, central governments cannot aid SNGs indiscriminately. So as to minimise such risks, support to SNGs should be well-targeted and used only in extraordinary circumstances.

The Global Financial Crisis (GFC) was one of these periods in which support to SNGs was justified. During the GFC, at least nine OECD countries ${ }^{25}$ reported that central governments supported SNGs through grants and they mostly used grants earmarked for specific purposes (Blöchliger et al. 2010a). Despite this support, SNGs' fiscal balances decreased substantially in the peak of the crisis and SNGs acted procyclically by cutting investment (refer to Fig. 7).

Similar to the GFC, the COVID-19 crisis also justifies central support to SNGs. Since SNGs are in charge of many key activities to tackle a pandemic, such as health, public order and safety, education, and, to some extent, social protection (refer to Fig. $5),{ }^{26}$ lack of fiscal capacity could hinder SNGs' ability to take the necessary measures to contain the virus and save lives.

This lack of fiscal capacity was expected, as an examination of the results of the survey on intergovernmental fiscal relations to tackle the COVID-19 crisis $^{27}$ reveals. In the first semester of 2020 countries were expecting SNGs to be heavily hit by the crisis. Not only was the death toll rising substantially at that time but also containment measures were generating a deep reduction in economic activity. At that time, unemployment was rising substantially as a result of the enforcement of lockdowns and forecasts were predicting a crisis significantly stronger than GFC. ${ }^{28}$ As a result, 17 out of 20 countries surveyed believed that SNGs' fiscal balances would deteriorate in 2020 as a consequence of the COVID-19 crisis. $^{29}$

For this reason, central governments stepped in to support SNGs in multiple countries. In the sample of countries surveyed, the most common response from central governments has been the provision of extraordinary grants (14 out of 23 countries). Eight countries temporarily lifted fiscal rules and five countries' central governments provided additional loans and guarantees to SNGs. In contrast to what happened in the GFC, funds provided were mostly non-earmarked, with no conditions attached, but SNGs often had to comply with additional accountability requirements. Figure 14 summarises the result of the survey.

Although lifting fiscal rules increases SNGs' room to manoeuvre it does not affect their liquidity in a direct manner. Regarding measures that do affect liquidity, no country supported SNGs through guarantees from the central/federal government nor through loans without providing them intergovernmental grants as well.

\footnotetext{
${ }^{25}$ Australia, Canada, France, Germany, Japan, Korea, Norway, Portugal and Spain (Blöchliger et al. 2010a).

${ }^{26}$ For further information on the role of SNGs in tackling the COVID-19 crisis, see Allain-Dupré et al. (2021), de Biase and Dougherty (2021), and Dougherty et al. (2020).

27 Survey was further described in the second section of this paper.

${ }^{28}$ See, for instance, Clemens and Veuger (2020).

${ }^{29}$ Australia, Austria, Belgium, Brazil, Canada, Colombia, Estonia, Finland, Iceland, Italy, Korea, Poland, Slovenia, South Africa, Spain, Switzerland, and the United States expected SNGs' fiscal balances to deteriorate in 2020 while Latvia, Luxembourg and Mexico did not.
} 


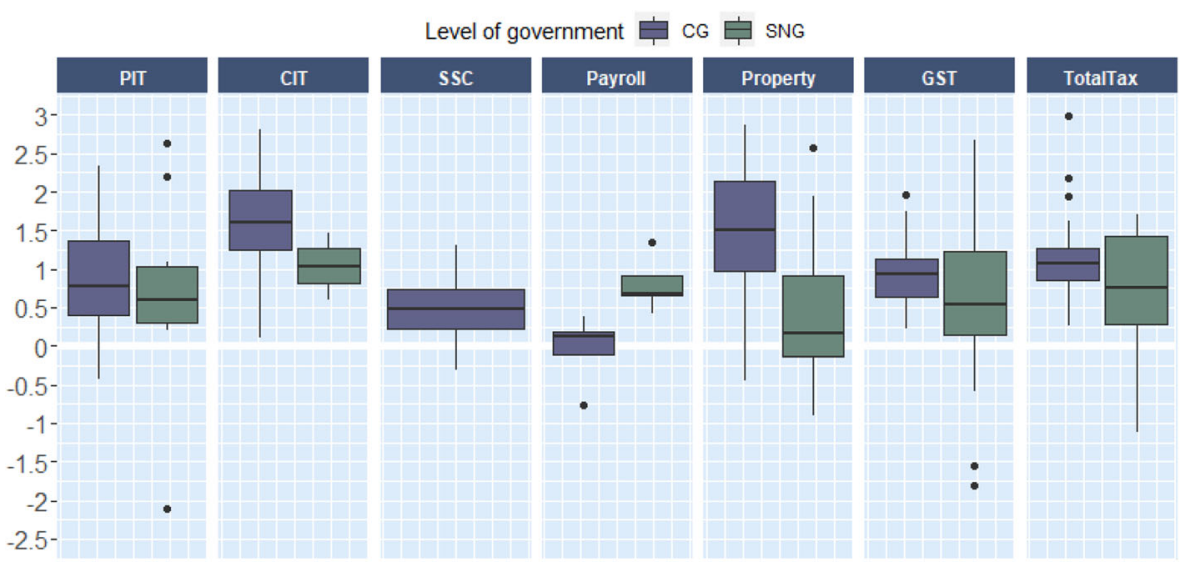

Fig. 9 Boxplot of the short-run buoyancy coefficient (y axis) of the 1-stage ECM model by level of government and tax. For visualisation purposes values are capped between -2.5 and +3 . Source: Authors' elaboration based on OECD System of National Accounts



Fig. 10 Boxplot of the short-run buoyancy coefficient (y axis) of the 2-stage ECM model using robust regression by level of government and tax. For visualisation purposes values are capped between -2.5 and +3 . Source: Authors' elaboration based on OECD System of National Accounts

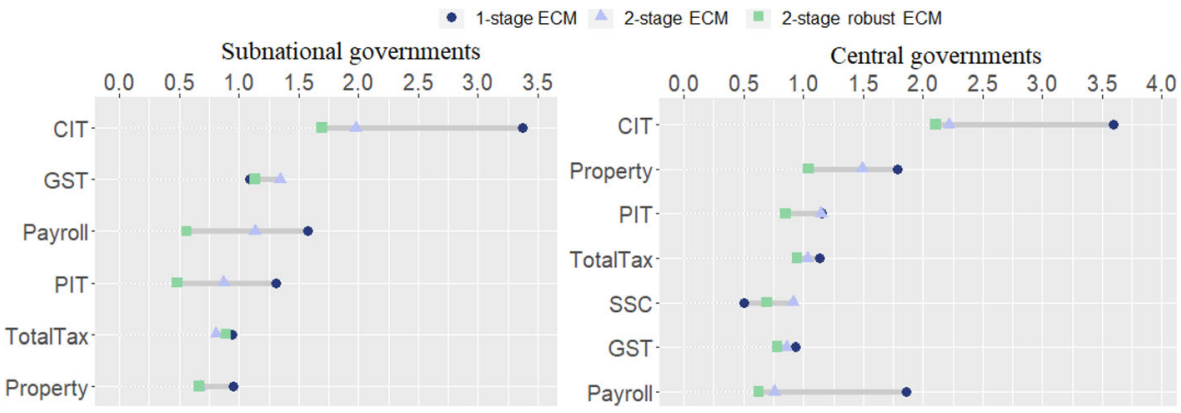

Fig. 11 Short-run buoyancy coefficient ( $\mathrm{x}$ axis) by tax type, level of government and model, using the mean group estimator. Tax types are ordered from highest to lowest buoyancy within each level of government. Source: Authors' elaboration based on OECD System of National Accounts 


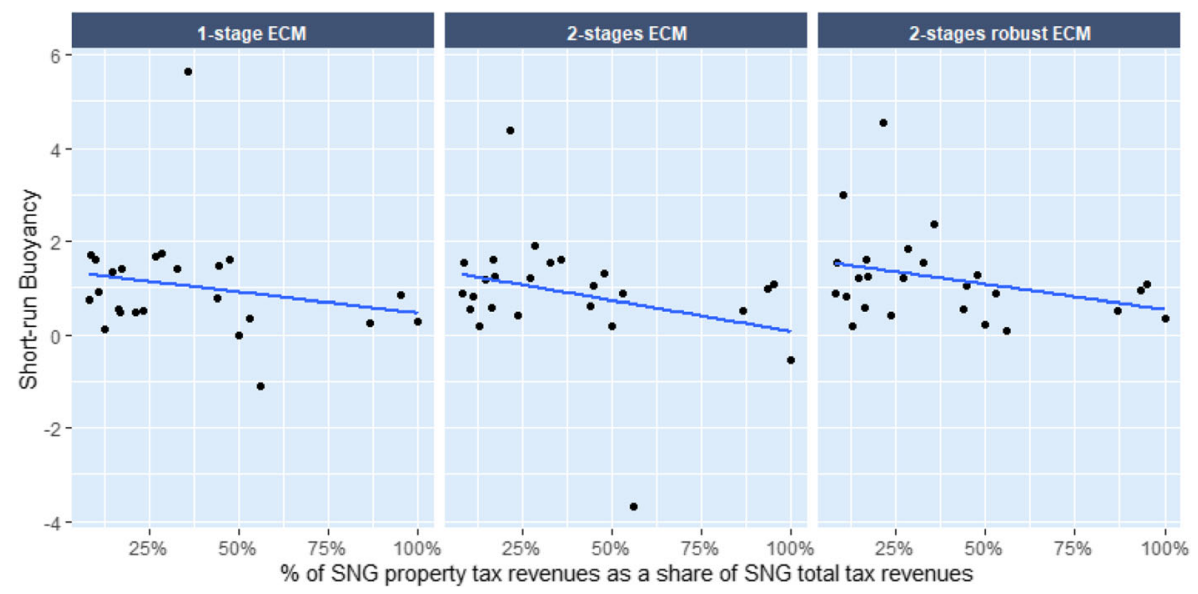

Fig. 12 Short-run buoyancy coefficient (y-axis) and percentage of SNG property tax revenues as a share of SNG total revenues (x-axis). The down-ward sloping tendency holds for all three models, although it is stronger when a non-robust estimator was used. Source: Authors' elaboration based on OECD System of National Accounts

The criteria to define the amount of funds transferred varied across countries. In some cases, central governments provided a fixed amount to SNGs, which was defined in advance based on an expectation of decrease in subnational revenues and increase in expenditures, often based on tax revenue forecasts, which were very pessimistic at the time.

The use of intergovernmental grants poses substantial costs to the central government. While loans are expected to be repaid in the future and guarantees might not generate any costs to central governments (except in the case of subnational default),

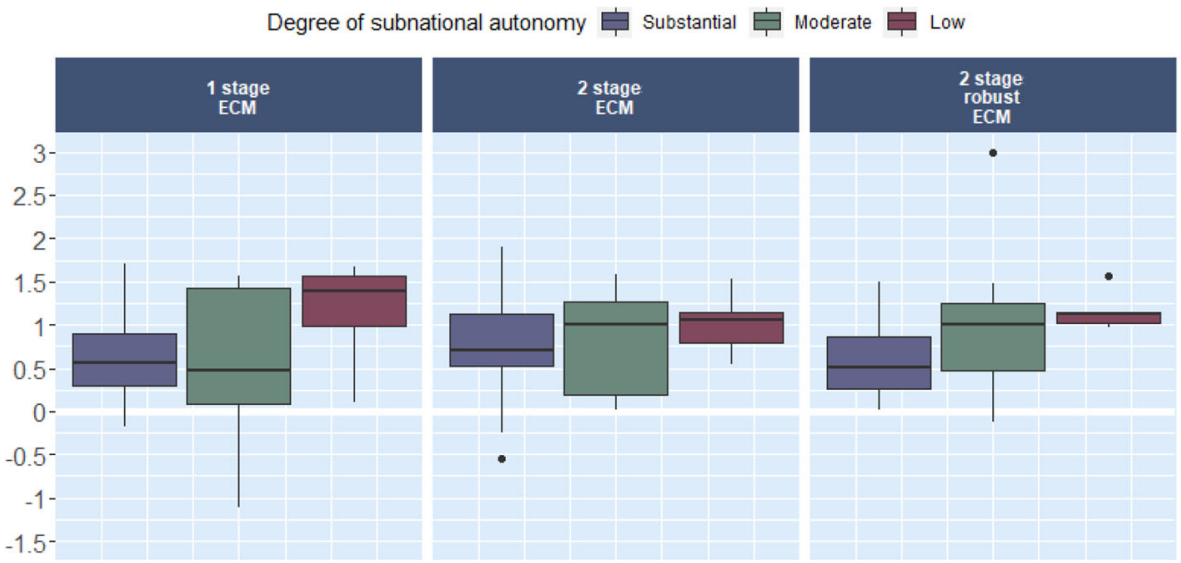

Fig. 13 Box plots of SNGs total tax short-run buoyancy coefficient (y-axis) grouped by SNG tax autonomy. Substantial autonomy means that SNGs have full discretion over tax rates of taxes that represent more than $50 \%$ of their total tax revenues. Low autonomy means that central governments have full discretion over tax rates and reliefs of taxes that represent more than $50 \%$ of SNGs total tax revenues. All other arrangements (e.g., SNGs having, for most of their taxes, discretion over tax rates within upper/lower bounds) are categorised as moderate autonomy. Source: Authors' elaboration based on OECD System of National Accounts and OECD Fiscal Decentralisation Database 


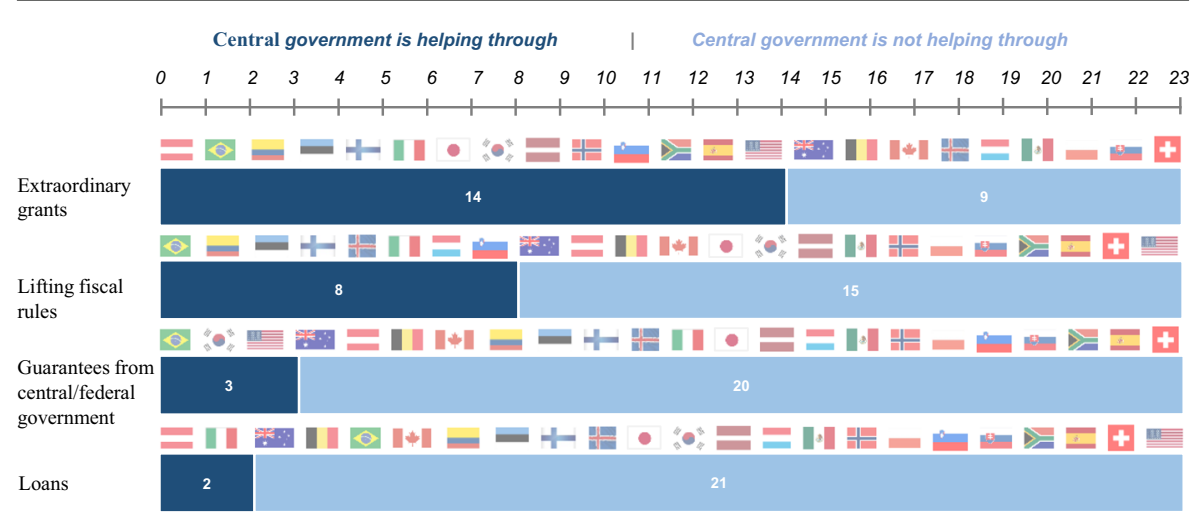

Fig. 14 Measures employed by central governments to improve subnational fiscal capacity in 2020. Source: Based on the COVID-19 Rapid Survey held by the Network in June 2020

intergovernmental grants are directly funded by central governments, leading to an increase in their debt levels. In case of over-dimensioned grants, SNGs might be better off after the crisis than they were before, while central governments may incur unnecessary expenses.

\section{Discussion}

\subsection{Conclusion and implications}

As SNGs have a crucial role in tackling the COVID-19 pandemic and as the pandemic has been extremely deadly, central governments seem to be sparing no effort to guarantee that SNGs have the necessary fiscal capacity to take the necessary measures to contain the virus and save lives. In addition, SNGs tend to have more stable tax revenues and to spend less in social protection programmes than central governments. As a result, it is expected that this crisis will have a greater impact on the fiscal position of central governments than on the fiscal position of SNGs.

Preliminary data from 2020 for six countries ${ }^{30}$ support this conclusion and even suggest that in some cases the support was over-dimensioned, as SNGs from some countries are better-off financially now than they were before the crisis had started. For instance, in Germany, the central government's revenues decreased $7.3 \%$ while SNGs revenues increased $4.6 \%$; at the same time the central government's and SNGs' expenditures increased $28.9 \%$ and $12.5 \%$, respectively. This means that the central government's finances in Germany were much more heavily impacted than those of the SNGs. This pattern repeated for all six countries for which preliminary fiscal data for 2020 was gathered (see Supplementary Material A7 for country-specific data).

On the bright side, SNGs are responsible for the bulk of public investment and, thus, they are less likely to cut investment as they did following the GFC, which may then not impair GDP growth as happened after the GFC. In addition, the COVID-19 crisis

\footnotetext{
${ }^{30}$ Brazil (Secretaria do Tesouro Nacional 2021), Germany (Destatis 2021), Portugal (Statistics Portugal 2021), Spain (Instituto Nacional de Estadística 2021; Ministerio de Hacienda 2021), Switzerland (Eidgenössische Finanzverwaltung 2021) and the United States (Bureau of Economic Analysis 2021).
} 
was not a balance-sheet crisis, for which recovery is more likely to be protracted (Jonas 2012). The pace of recovery and the level of investment in the aftermath of the crisis are still, of course, highly uncertain.

Not only is the pace of the recovery of the economy uncertain but also the pace at which tax revenue may follow the evolution of tax bases. Owing to specific tax collection mechanisms such as declaration based on past income/transactions or tax loss carry-forwards, taxes are sometimes collected with lags (Princen et al. 2013). More notably at the SNG levels, in many countries the intergovernmental transfer system reacts with a lag of 1-2 years to the cycle, which may have postponed a reduction in subnational tax revenues.

Another relevant issue is whether the existing fiscal arrangements are resilient to shocks. In that regard, this piece concludes that SNG tax revenues tend to be more stable than those of the central governments. That is because SNGs tend to rely more on recurrent taxes on immovable property, whose tax base is not directly related to the economic cycle. Nevertheless, despite the fact that this type of tax provides stable revenues and are growth-friendly, it is not always the best tax to promote income equality (Cournède et al. 2018). As a result, revenue-neutral tax reforms towards revenue stability cannot be achieved without some trade-offs. Finding a good balance is nontrivial, but it seems that most countries can increase reliance on property taxation as property is by and large undertaxed.

Furthermore, also with regard to the resilience of subnational tax systems, if central governments frequently support SNGs in economic downturns through intergovernmental grants, SNGs might not have the incentive to have a resilient fiscal structure and may export the costs of their policies to central governments. ${ }^{31}$ This can be especially problematic in cases in which central support is frequent since there is evidence that as countries increase their reliance on intergovernmental transfers over time, subnational and overall fiscal performance declines (Rodden 2002) and that, in the case of frequent lifting of fiscal rules, governments that have a reputation of not committing to enforce fiscal rules tend to increase subnational over-borrowing, which historically has led to transfers or bailouts by central governments (Dovis and Kirpalani 2020).

It is worth noting that the support given to SNGs was given mostly on an ad hoc basis. Therefore, the existence and size of such support in future crises is uncertain and may depend on political choices. A highly unexplored option is for countries to implement an intergovernmental arrangement that increases grants in times of crisis, by prior design. ${ }^{32}$ In that manner, not only would the size and existence of the support be predictable, allowing for SNGs to plan their fiscal systems accordingly, but also political gridlock could be avoided. The design of such arrangement could be, however, challenging.

\footnotetext{
${ }^{31}$ This is more critical the more autonomy SNGs have. In some countries, for instance, the United States, SNGs do actually have substantial tax, expenditure, and policy autonomy and, thus, in principle, they can build resilient fiscal systems and could bear the cost of their own policy measures and, if needed, could get loans directly from financial markets.

${ }^{32}$ For instance, in times of crisis (when a triggering criterion related to the economic activity is triggered) intergovernmental grants are automatically supplemented with additional funds, defined by a pre-established formula.
} 


\subsection{Limitations and future work}

As a first analysis on a cross-country basis of tax buoyancy across levels of government, this piece applied a relatively simple method for estimating tax buoyancies that can be improved incrementally. Here the main limitations of the method employed are briefly discussed.

First, this study did not take into account the fact that individual jurisdictions have different tax and socioeconomic structures and, thus, also buoyancies. For instance, earlier research found that US states varied considerably in their degree of revenue cyclicality as a result of differences in tax mix, tax structures and the willingness to adjust tax policy over the course of the business cycle (Bruce et al. 2006; Kodrzycki 2014). In addition, subnational jurisdictions tend to rely more on specific sectors that are more developed in their regions. That means that not only regional economic factors can affect tax buoyancy (see Brockmyer 2014) but also that in the time of the COVID-19 crisis, jurisdictions that rely heavily on some certain sectors (e.g., tourism) have suffered substantially more than others.

Second, the buoyancy parameter was assumed to be constant throughout the cycle, but tax elasticities and buoyancies might change over time. ${ }^{33}$ In the case of an analysis of tax buoyancies across levels of government this over-time variation can be exacerbated by (de)centralisation of tax revenues. In other words, when tax collection or discretion over tax policy changes hands (i.e., from SNG to central governments or vice versa), tax buoyancies and elasticities of each level of government involved are likely to change. Controlling for such changes in taxation might provide interesting insights.

Third, using tax bases instead of GDP can be useful in such an asymmetric crisis. In other words, the impact of the COVID-19 crisis is asymmetrical across tax bases and, thus, using each tax base individually instead of GDP could potentially more faithfully represent the nature of the current crisis.

Supplementary Information The online version contains supplementary material available at https://doi.org/ 10.1007/s10368-021-00518-1.

Acknowledgements We would like to thank the special issue editors and referees, our seminar discussant, Istvan Szekely (DG-ECFIN), and seminar participants for their feedback. This research was initially prepared as background to discussions of the OECD Network on Fiscal Relations across Levels of Government, and relies in part upon a survey of delegates regarding policy responses to the COVID-19 crisis implemented by central governments to support the finances of subnational governments. We also wish to express our gratitude to these delegates and Julie Corberand, who helped gather the preliminary data of 2020 for a sample of countries. This data was crucial to confirm our expectations that the central governments' finances were more heavily affected than those of subnational governments in this crisis. The views expressed in this paper are solely those of the authors and do not necessarily represent those of the OECD or its member countries.

\footnotetext{
$\overline{33}$ Belinga et al. (2014) has explored this topic and concluded that tax buoyancy for total tax revenue is larger during contractions than during growth while Bruce et al. (2006) reveals that tax bases tend to grow less/more than would be expected from the short-run elasticity when above/below equilibrium. Mourre and Princen (2015) concludes that for all types of revenue but consumption taxes, it seems that the elasticity varies over the cycle with CIT's elasticity being especially dependent on it. Dudine and Jalles (2017) concluded that tax revenues tend to react more counter-cyclically during recessionary periods.
} 


\section{References}

D. Allain-Dupré et al. (2021) The territorial impact of COVID-19: managing the crisis across levels of government. OECD Tackling Coronavirus, April, 2-44

R. Almy (2014) Valuation and assessment of immovable property. OECD working papers on fiscal federalism, 19. https://doi.org/10.1787/5jz5pzvr28hk-en

J.E. Anderson, S.N. Shimul (2018) State and local property, income, and sales tax elasticity. National Tax J 71(3):521-546. https://doi.org/10.17310/ntj.2018.3.04

V. Belinga et al (2014) Tax buoyancy in OECD countries. IMF Work Pap 14(110):1. https://doi.org/10.5089/ 9781498305075.001

D. Bergvall et al (2006) Intergovernmental transfers and decentralised public spending. OECD working papers on fiscal federalism 3:1-76. https://doi.org/10.1787/5k97b11z2hxw-en

P. de Biase, S. Dougherty (2021) Federalism and public health decentralisation in the time of COVID-19. OECD working papers on fiscal federalism, 33. http://oe.cd/il/FFwp33

H. Blöchliger, J.C. Pinero (2011) Tax competition between sub-central governments. OECD economics department working papers, 13. https://doi.org/10.1787/5k97b1120t6b-en

H. Blöchliger et al. (2010a) Fiscal policy across levels of government. OECD working papers on fiscal federalism, 12. https://doi.org/10.1787/5k97b10wqn46-en

H. Blöchliger et al. (2010b) Sub-central governments and the economic crisis: impact and policy responses. OECD economics department working papers no. 752 . https://doi.org/10.1787/5kml6xq5bgwc-en

B. Brockmyer (2014) Managing uncertainty: how state budgeting can smooth revenue volatility. The Pew Charitable Trusts Report

D. Bruce et al (2006) Tax Base elasticities: a multi-state analysis of long-run and short-run dynamics. South Econ J 73(2):315. https://doi.org/10.2307/20111894

Bureau of Economic Analysis (2021) National income and product accounts. https://apps.bea.gov/iTable/ iTable.cfm?reqid=19\&step=2\&isuri=1\&categories=international

J. Clemens, S. Veuger (2020) Fiscal federalism and the COVID-19 shock in the US. VoxEU CEPR Policy Portal, 1-5

B. Cournède et al. (2018). Public finance structure and inclusive growth. OECD economic policy papers, 25. https://doi.org/10.1787/e99683b5-en

Y. Croissant, G. Millo (2019) Panel data econometrics with R (1st ed.). Wiley

Y. Deli et al. (2018) Dynamic tax revenue buoyancy estimates for a panel of OECD countries. ESRI Working Paper, No. 592. https://www.esri.ie/system/files?file=media/file-uploads/2018-03/WP592.pdf

Destatis (2021) Expenditure of the overall public budget 2019 and 2020. https://www.destatis.de/EN/Themes/ Government/Public-Finance/Expenditure-Revenue-And-Financial-Balance-Of-Public-Budgets/Tables/ expenditure.html

S. Dougherty, L. Phillips (2019) The spending power of sub-national decision makers across five policy sectors. OECD working papers on fiscal federalism, 25. http://oe.cd/il/FFwp25

S. Dougherty et al. (2019) Twenty years of tax autonomy across levels of government: measurement and applications. OECD working papers on fiscal federalism, 29. http://oe.cd/il/FFwp29

S. Dougherty et al. (2020) COVID-19 and fiscal relations across levels of government. OECD tackling coronavirus, April, 2-22

A. Dovis, R. Kirpalani (2020) Fiscal rules, bailouts, and reputation in Federal Governments. Am Econ Rev 110(3):860-888. https://doi.org/10.1257/aer.20181432

P. Dudine, J. T. Jalles (2017) How buoyant is the tax system? New evidence from a large heterogeneous panel IMF working papers. https://doi.org/10.1002/jid.3332

Eidgenössische Finanzverwaltung (2021) Öffentliche Finanzen der Schweiz gemäss FS und GFS Modellen. https://www.efv.admin.ch/dam/efv/de/dokumente/finanzstatistik/daten/main_extern.xlsx

W. Enders (2014) Applied time series econometrics (4th ed.). Wiley. https://doi.org/10.1017/ CBO9780511606885

L. Eyraud et al. (2020) How to design subnational fiscal rules. International Monetary Fund

J. Fox (2015) Applied regression analysis and generalized linear models (3rd ed.). SAGE Publications

J. Haughton (1998) Estimating tax buoyancy, elasticity, and stability. African economic policy paper, 11

J. Hindriks, G. Myles (2013). Intermediate public economics. MIT Press (ed.). https://doi.org/10.1017/ CBO9781107415324.004

IMF (2021) Fiscal monitor, April. www.imf.org/en/Publications/FM/Issues/2021/03/29/fiscal-monitor-april2021 
Instituto Nacional de Estadística (2021) Spain: economic and financial data. https://www.ine.es/dynt3/FMI/? $\mathrm{L}=1$

G.P. Jenkins et al. (2000). Tax analysis and revenue forecasting: issues and techniques. Duke University Press

J. Jonas (2012) Great recession and fiscal squeeze at U.S. subnational government level. IMF Work Pap 12(184):1. https://doi.org/10.5089/9781475505320.001

Y.K. Kodrzycki (2014) Smoothing state tax revenues over the business cycle: gauging fiscal needs and opportunities. Federal Reserve Bank of Boston, 14-11. https://doi.org/10.2139/ssrn.2555870

G. Koester, C. Priesmeier (2012) Estimating dynamic tax revenue elasticities for Germany. Bundesbank discussion paper, 23

G. Köster, C. Priesmeier (2017) Revenue elasticities in euro area countries: an analysis of long-run and shortrun dynamics. ECB working paper series 1989. https://doi.org/10.20955/r.85.67

M. Koller, W.A. Stahel (2011) Sharpening Wald-type inference in robust regression for small samples. Comput Stat Data Anal 55:2504-2515. https://doi.org/10.1016/j.csda.2011.02.014

R. Lagravinese et al (2020) Tax buoyancy in OECD countries: new empirical evidence. J Macroecon 63(October 2019):103189. https://doi.org/10.1016/j.jmacro.2020.103189

B.F. Lutz (2008) The connection between house price appreciation and property tax revenues. Finance and economics discussion series, 48. https://doi.org/10.17016/feds. 2008.48

T.D. Mattina, V. Gunnarsson (2007) Budget rigidity and expenditure efficiency in Slovenia. IMF Work Pap 07(131):1. https://doi.org/10.5089/9781451866957.001

J.L. Mikesell (2012) Administration of local taxes: an international review of practices and issues for enhancing fiscal autonomy. In: A primer on property tax: administration and policy (pp. 307-338). Wiley

Ministerio de Hacienda (2021). Presupuestos de las Comunidades Autónomas. https://serviciostelematicosext. hacienda.gob.es/SGCIEF/PublicacionPresupuestos/aspx/MenuREP.aspx

G. Mourre, S. Princen (2015) Tax revenue elasticities corrected for policy changes in the EU. EC discussion paper 018. https://doi.org/10.2765/622532

W. Oates (1972) Fiscal federalism. Edward Elgar Publishing

R.W.R. Price et al. (2015) Adjusting fiscal balances for the business cycle: new tax and expenditure elasticities estimates for OECD countries. OECD economics department working papers, 1275. https://doi.org/10. 1787/5jrp1g3282d7-en

S. Princen et al. (2013) Discretionary tax measures: pattern and impact on tax elasticities. European Commission economic papers 499, May. https://doi.org/10.2765/44081

J. Rodden (2002) The dilemma of fiscal federalism: Grants and fiscal performance around the world. Am J Polit Sci 46(3):670. https://doi.org/10.2307/3088407

W. Roland, P. Smoke (2005) East Asia decentralizes. In: East Asia decentralizes: making local government work. The World Bank. https://onlinelibrary.wiley.com/doi/abs/10.1111/1467-8551.12006

M.J. Rozell, C. Wilcox (2019) Federalism. Oxford University Press

Secretaria do Tesouro Nacional (2021). Boletim Trimestral de Estatisticas Fiscais do Governo Geral. https:// www.tesourotransparente.gov.br/publicacoes/boletim-trimestral-de-estatisticas-fiscais-do-governo-geral/ $2020 / 25$

D. Shoag et al. (2017) Rules versus home rule: local government responses to negative revenue shocks. American Enterprise Institute Working Paper. https://doi.org/10.2139/ssrn.3017533

Statistics Portugal (2021) Main aggregates of general government - 2020. https://www.ine.pt/xportal/xmain? xpid=INE\&xpgid=ine_destaques

T. Ter-Minassian (2020) Intergovernmental fiscal cooperation and subnational revenue autonomy. InterAmerican Development Bank DP 748. https://publications.iadb.org/publications/english/document/ Intergovernmental_Fiscal_Cooperation_and_Subnational_Revenue_Autonomy.pdf

C. Vammalle, I. Bambalaite (2021) Fiscal rules for subnational governments: the devil's in the details. OECD working papers on fiscal federalism, 35. http://oe.cd/il/FFwp35

G. Wolswijk (2009) The short- and long-run tax revenue response to changes in tax bases. Econ Bull 29(3): 1960-1970

V.J. Yohai (1987) High breakdown-point and high efficiency estimates for regression. Ann Stat 15:642-665

Publisher's note Springer Nature remains neutral with regard to jurisdictional claims in published maps and institutional affiliations. 